\title{
Serum osteopontin values in patients with ischemic stroke
}

\section{İskemik inmeli hastalarda serum osteopontin değerleri}

\author{
Rezzak Yillmaz ${ }^{1}$, Asli Bolayir²
}

1 Christian-Albrechts University of Kiel, Department of Neurology, Kiel, Germany

2 Cumhuriyet University, Faculty of Medicine, Department of Neurology, Sivas, Turkey

Corresponding author: Rezzak Yilmaz, Christian-Albrechts University of Kiel,Department of Neurology, Arnold-Heller-Str. 3, 24105, Kiel,

Germany

E-mail: rezzak.yilmaz@uksh.de

Received/Accepted: October 12, 2018 / March 26, 2019

Conflict of interest: There is not a conflict of interest.

\section{SUMMARY}

Objective: Osteopontin (OPN) is an extracellular matrix protein which has been associated with immune response and tissue repair in the central nervous system.

We set out to investigate the OPN values and its association with clinical features in patients with ischemic stroke.

Method: Serum OPN values of 35 patients with ischemic stroke were compared with 35 controls at the admission and at the seventh day following the event. Correlations between OPN levels and disease specific features were also calculated.

Results: Serum OPN values were not significantly different between patients and controls at baseline. In patients, an increase in OPN values was detected at follow-up which was significantly higher than the controls. The OPN levels were not correlated with infarct size or disease severity.

Conclusions: Serum OPN levels increase not in the hyperacute/acute phase of the stroke but in the subacute phase. No association with disease severity or lesion volume is detected.

Keywords: Osteopontin, Stroke

\section{ÖZET}

Amaç: Osteopontin merkezi sinir sisteminde immün yanıt ve doku tamiri ile ilișkili bir ekstraselüler matrix proteinidir. İskemik inmeli hastalarda osteopontin değerlerini ve bu değerlerin klinik bulgular ile olan ilişkisini tespit etmektir.

Yöntem: Çalışma kapsamında 35 hastanın inmenin ilk günü ve yedinci günü serum osteopontin seviyeleri 35 kontrol ile karşılastırıldı. Ayrıca osteopontin değerleri ve hastalık özellikleri arasındaki korelasyon incelendi.

Bulgular: İnmenin ilk günü ölçülen osteopontin değerlerinde hastalar ve kontroller arasında anlamlı fark bulunmadı. Hastaların yedinci gün değerleri ise kontrollere oranla anlamlı derecede yüksekti. Osteopontin degerleri infarkt büyüklüğü ya da hastalık derecesi ile anlamlı korelasyon göstermedi.

Sonuç: Serum osteopontin değerleri inmenin hiperakut/akut evresinden cok subakut döneminde yükselmektedir. Osteopontin yüksekliği, infarkt boyutu veya klinik durumdan bağımsız olabilir.

Anahtar sözcükler: Osteopontin, inme

\section{INTRODUCTION}

Osteopontin (OPN) is an extracellular glycoprotein which is expressed by macrophages, CD-4 lymphocytes, endothelial cells or vascular smooth muscle cells playing a functional in inflammation and malignancies ${ }^{1}$. It has been reported that OPN is involved in angiogenesis, wound healing and tissue homeostasis as well as the regulation of the immune response ${ }^{2,3}$. Neuroprotective or repair promoting effects by the modulation of microglia by OPN has also been detected in central nervous system injury ${ }^{4,5}$. In cerebral ischemia OPN is shown to be released in the peri-infarct zone by microglia and macrophages in the subacute phase ${ }^{6-8}$. Besides, decrease in the infarct volume in rats has been shown with intraventricular and intranasal application of $\mathrm{OPN}^{9,10}$. However, most of these results were collected from non-human studies with experimental stroke models and there has been relatively fewer studies with patients ${ }^{11,12}$. 
Therefore, in this study we aimed to investigate the OPN values and their association with disease characteristics in the clinical setting in patients with ischemic stroke.

\section{MATERIAL AND METHODS}

\section{Participants}

Patients with a diagnosis of cerebral ischemia who attended to the stroke unit of Cumhuriyet University, Department of Neurology within 24 hours were recruited between 03.2016- 03.2017. The diagnosis of ischemic stroke was confirmed by magnetic resonance imaging or a follow-up computerized tomography. Lesion volume is calculated by $\mathrm{ABC} / 2$ formula (ellipsoid) which was provided by the imaging software. Patients with acute inflammatory diseases as well as myocardial infarction within 3 months, acute heart failure, renal or hepatic failure were excluded based on patient history and hospital records. Disease severity was documented using Glasgow Coma Scale (GCS), National Institutes of Health Stroke Scale (NIHSS) and Modified Rankin Scale (MRS). A control group which was demographically similar to the patient group was also recruited. The study was approved by the ethics committees of the Medical Faculty of the Cumhuriyet University (2015-12/01). All procedures were in accordance with the Declaration of Helsinki and an informed consent was obtained from all participants.

\section{Sample collection}

Blood samples of $5 \mathrm{ml}$. were taken from all participants at the admission and from the patients at the seventh day of stroke. Withdrawn samples were centrifuged in $2000 \mathrm{~g} 15$ minutes at $4^{\circ} \mathrm{C}$ and were stored at $-80{ }^{\circ} \mathrm{C}$. Analyses of OPN were performed by means of standard operating procedures using an Elisa-Kit Boster Biological Technology Co.,Ltd, Pleasanton, CA, USA.

\section{Statistics}

Descriptive and quantitative data are given as mean and standard deviation (SD). Differences between patient and control groups were analyzed using a Chi-squared test or an Independent samples t-test, whereas within-group comparisons of the patient group were performed by Paired sample's t-test. Correlations between OPN values and disease severity were calculated by Spearman's test. The significance threshold was set to $p<0.05$. SPSS Statistics 21.0.0 (SPSS Ltd., Chicago, IL) was used.

\section{RESULTS}

After the exclusion of 3 participants due to myocardial infarction or renal failure a total of 70 participants were included in the study of which, 35 were patients. The demographic characteristics of the study participants are shown in Table-1. The patient and control groups were not significantly different in terms of age, gender, history of hypertension, diabetes and smoking ( $p>$ 0.1 , Table-1). The follow-up scores of disease severity measured by GCS and MRS showed a significant improvement at the seventh day in the patient group

Table 1: Demographic characteristics of the groups

\begin{tabular}{llll}
\hline & Patients $(\mathrm{n}=35)$ & Controls $(\mathrm{n}=35)$ & P value \\
\hline Age, mean (SD) & $70(11.7)$ & $68.9(7.9)$ & 0.65 \\
Female gender n, (\%) & $16(45.7)$ & $19(54.3)$ & 0.47 \\
History of hypertension n, (\%) & $20(57.1)$ & $18(51.4)$ & 0.63 \\
History of diabetes n, (\%) & $11(31.4)$ & $10(28.6)$ & 0.79 \\
History of smoking n, (\%) & $12(34.2)$ & $10(28.6)$ & 0.62 \\
\hline
\end{tabular}

With regard to baseline OPN values patient and control groups did not display a significant difference $(p=0.36)$. Baseline and follow-up OPN values were significantly correlated $(\mathrm{r}=0.48, \mathrm{p}=$ $0.004)$. The OPN values of patients at follow-up were higher than baseline which and showed a trend towards significance $(p=0.057)$ in Paired sample's t-test. A significant difference was detected between the follow-up OPN values of the patients and the control group ( $\mathrm{p}=0.009)$. Lesion volume was strongly correlated with all scales of disease severity (GCS $(\mathrm{r}=-.85)$, NIHSS $(\mathrm{r}=.81)$ and MRS $(r=.77)(p<0.001)$, however, no significant correlation between these assessments and OPN levels was detected at baseline or follow-up. The results are summarized in Table- 2 and 3. 
Table 2: Disease characteristics and ostepontin values

\begin{tabular}{lllll}
\hline & $\begin{array}{l}\text { Patients } \\
\text { admission } \\
(\mathrm{n}=35)\end{array}$ & $\begin{array}{l}\text { Patients } \\
7^{\text {th }} \text { day }(\mathrm{n}=35)\end{array}$ & $\begin{array}{l}\text { Controls } \\
(\mathrm{n}=35)\end{array}$ & P value \\
\hline GCS mean, (SD) & $12.6(3.0)$ & $13.3(3.0)$ & - & 0.012 \\
NIHSS mean, (SD) & $7.7(6.2)$ & $7.1(7.1)$ & - & 0.12 \\
MRS mean, (SD) & $2.6(1.5)$ & $2.2(1.8)$ & - & $<0.001$ \\
Lesion volume mm mean, (SD) & $77.3(92.5)$ & - & - & - \\
Osteopontin ng/ml mean, (SD) & $12.0(12.5)$ & $16.7(14.3)$ & $10.0(2.0)$ & $0.36^{*}$ \\
& & & & $0.057^{* * *}$ \\
& & & & $0.009^{* * *}$ \\
\hline
\end{tabular}

$*$ Patients vs. Controls at baseline

**Patients baseline vs. $7^{\text {th }}$ day

$* * *$ Patients $7^{\text {th }}$ day vs. Controls

GCS, Glasgow Coma Scale; NIHSS, National Institutes of Health Stroke Scale; MRS, Modified Rankin Scale

Table 3: Correlations between osteopontin values and disease features

\begin{tabular}{llllllll}
\hline & $\begin{array}{l}\text { Lesion } \\
\text { volume }\end{array}$ & $\begin{array}{l}\text { GCS } \\
\text { admission }\end{array}$ & $\begin{array}{l}\text { GCS } \\
7^{\text {th }} \text { day }\end{array}$ & $\begin{array}{l}\text { NIHSS } \\
\text { admission }\end{array}$ & $\begin{array}{l}\text { NIHSS } \\
7^{\text {th }} \text { day }\end{array}$ & $\begin{array}{l}\text { MRS } \\
\text { admission }\end{array}$ & $\begin{array}{l}\text { MRS } \\
7^{\text {th }} \text { day }\end{array}$ \\
\hline OPN admission, r & -0.20 & 0.27 & 0.05 & -0.30 & -0.21 & -0.27 & -0.21 \\
${\text { OPN } 7^{\text {th }} \text { day, } r}$ & -0.20 & 0.13 & 0.17 & -0.18 & -0.30 & -0.23 & -0.21 \\
\hline
\end{tabular}

$\mathrm{r}$, correlation coefficient in Spearman's test, P value for all $>0.05$

GCS, Glasgow Coma Scale; NIHSS, National Institutes of Health Stroke Scale; MRS, Modified Rankin Scale

\section{DISCUSSION}

In this study, we have found an increase in OPN values of the patients compared to controls in the subacute phase of cerebral ischemia. The lack of a significant difference between two groups at baseline may suggest that OPN levels stay normal in the hyperacute to acute phase following a cerebral ischemia. Moreover, the results showed no significant correlation between the OPN values and disease severity measured by lesion volume and clinical scales.

It has previously been showed that OPN levels increase in the 3-6 days with the inflammation following a cerebral ischemia ${ }^{3,13 .}$ With this regard, our results are in line with previous findings. However, although not significantly different from controls, the OPN values in the patient group were widely distributed as seen in the relatively large SD (Table-2) indicating that a subgroup of patients may have displayed an OPN increase at the hyperacute/acute phase. The detection of OPN mRNA expression in the peri-infarct region even in the first hours following a stroke supports this assumption? ${ }^{7}$. Nevertheless, it can be postulated that an OPN increase in the local tissue may not be reflected in the circulation and detected in serum samples immediately following an ischemia at least at group level. Evaluating the levels of extracellular matrix proteins in the hyperacute/acute phase in patients with cerebral ischemia, Ozaki et al. found an increase in "thrombin-cleaved OPN N-terminal" (trOPN-N), a fragment of OPN, but not in OPN itself which further supports our results ${ }^{12}$.

Although a significant increase in the subacute phase of ischemia was detected, the magnitude of the OPN increase was significantly correlated neither with lesion volume nor disease severity. This is also in line with Ozaki et al. who did not find a correlation between OPN levels and infarct size, concomitant diseases, symptom duration or NIHSS scores ${ }^{12}$. Similarly, no correlation between OPN levels and blood pressure in patients with carotid plaques that undergone endarterectomy was found ${ }^{11}$. Given the fact that the OPN expression has been associated with inflammation and tissue damage ${ }^{1}$ and an OPN expression in the peri-infarct region has been detected ${ }^{7}$, one would expect a linear relationship between the infarct size and OPN levels. However, it seems that this is not the case taking into account of the negative results of the above mentioned clinical studies including our study. These results propose that the OPN expression may be independent from the clinical features such as infarct size or disease 
severity and may rather mediated by other intrinsic factors.

Another issue that should be taken into account is the etiology of the stroke since the pathophysiological mechanisms of the common ischemic stroke subtypes are diverse. With this regard it may be plausible to expect an increase in OPN a level following an atherothrombotic stroke, since an OPN expression by macrophages has been detected abundantly in inflamed atherosclerotic plaques ${ }^{14}$ and the plaque rupture may cause an OPN increase. However, the results were inconsistent with that assumption at least with regard to OPN in the study from Ozaki et al. who compared patients with athreothrombotic and non-atherothrombotic subtypes and found no significant difference in OPN levels between groups. Interestingly, a significant increase was found only in trOPN-N in the atherothrombotic group $^{12}$. The lack of etiological subtyping is a limitation of the current study.

More shortcomings of the study also have to be mentioned. The lack of follow-up OPN assessment in the control group is the main limitation of our study. The comparison between the follow-up OPN values of the patients and baseline values of controls was based on the reasoning that the OPN values do not change in controls unlike the patient group. Although this may be plausible, it should be confirmed in further studies. Moreover, even though patients with inflammatory diseases or conditions such as renal or hepatic failure or myocardial infarction were excluded, the absence of further exclusion criteria or assessment of alternative inflammatory markers to rule out other conditions with an OPN increase should also be regarded as a limitation. Lack of assessment of the OPN fragments, especially the trOPN-N is another limitation considering that trOPN-N may be more sensitive than OPN as an elevation in the earlier stroke phase and an association with stroke etiology was detected in contrast to OPN. On the other hand, well defined and meticulously assessed patient and control groups, lack of missing data and although relatively short the prospective design are the strengths of the study.

\section{CONCLUSION}

In conclusion, our data suggests an increase in OPN values in stroke patients not in the hyperacute to acute phase but in the subacute phase of the disease without any correlation with lesion volume or disease severity. Further longitudinal studies are needed to highlight the clinical interpretation of OPN values in stroke patients.

\section{REFERENCES}

1. Mazzali M, Kipari T, Ophascharoensuk V, Wesson JA, Johnson R, Hughes J. Osteopontin--a molecule for all seasons. QJM [Internet]. 2002 Jan [cited 2018 Dec 7];95(1):3-13.

2. Wang KX, Denhardt DT. Osteopontin: Role in immune regulation and stress responses. Cytokine Growth Factor Rev [Internet]. 2008 Oct [cited 2018 Dec 7];19(5-6):333-45. Available from: http://www.ncbi.nlm.nih.gov/pubmed/189 52487

3. Ladwig A, Rogall R, Hucklenbroich J, Willuweit A, Schoeneck M, Langen K-J, et al. Osteopontin Attenuates Secondary Neurodegeneration in the Thalamus after Experimental Stroke. J Neuroimmune Pharmacol [Internet]. 2018 Nov 28 [cited 2018 Dec 7]; Available from: http://link.springer.com/10.1007/s11481 018-9826-1

4. Schroeter M, Zickler P, Denhardt DT, Hartung H-P, Jander S. Increased thalamic neurodegeneration following ischaemic cortical stroke in osteopontin-deficient mice. Brain [Internet]. 2006 Jun 13 [cited 2018 Dec 7];129(Pt 6):1426-37. Available from:

https://academic.oup.com/brain/articlelookup/doi/10.1093/brain/awl094

5. Gliem M, Krammes $\mathrm{K}$, Liaw L, van Rooijen N, Hartung H-P, Jander S. Macrophage-derived osteopontin induces reactive astrocyte polarization and promotes re-establishment of the blood brain barrier after ischemic stroke. Glia [Internet]. 2015 Dec [cited 2018 Dec 7];63(12):2198-207. Available from: http://doi.wiley.com/10.1002/glia.22885

6. Wang X, Louden C, Yue TL, Ellison JA, Barone FC, Solleveld HA, et al. Delayed expression of osteopontin after focal stroke in the rat. J Neurosci [Internet]. 1998 Mar 15 [cited 2018 Dec 7];18(6):2075-83. Available from: http://www.ncbi.nlm.nih.gov/pubmed/948 2794

7. Ellison JA, Velier JJ, Spera P, Jonak ZL, Wang X, Barone FC, et al. Osteopontin and its integrin receptor alpha(v)beta3 are 
upregulated during formation of the glial scar after focal stroke. Stroke [Internet]. 1998 Aug [cited 2018 Dec 7];29(8):1698706; discussion 1707. Available from: http://www.ncbi.nlm.nih.gov/pubmed/970 7214

8. Ladwig A, Walter HL, Hucklenbroich J, Willuweit A, Langen K-J, Fink GR, et al. Osteopontin Augments M2 Microglia Response and Separates M1- and M2Polarized Microglial Activation in Permanent Focal Cerebral Ischemia. Mediators Inflamm [Internet]. 2017 [cited 2018 Dec 7];2017:7189421. Available from:

https://www.hindawi.com/journals/mi/201 7/7189421/

9. Meller R, Stevens SL, Minami M, Cameron JA, King S, Rosenzweig H, et al. Neuroprotection by osteopontin in stroke. $\mathrm{J}$ Cereb Blood Flow Metab [Internet]. 2005 Feb 28 [cited 2018 Dec 7];25(2):217-25. Available from: http://journals.sagepub.com/doi/10.1038/sj .jcbfm.9600022

10. Doyle KP, Yang T, Lessov NS, Ciesielski TM, Stevens SL, Simon RP, et al. Nasal administration of osteopontin peptide mimetics confers neuroprotection in stroke. J Cereb Blood Flow Metab [Internet]. 2008 Jun 26 [cited 2018 Dec 7];28(6):1235-48. Available from: http://journals.sagepub.com/doi/10.1038/jc bfm.2008.17

11. Wolak T, Sion-Vardi N, Novack V, Greenberg G, Szendro G, Tarnovscki T, et al. N-Terminal Rather Than Full-Length Osteopontin or Its C-Terminal Fragment Is Associated With Carotid-Plaque Inflammation in Hypertensive Patients. Am J Hypertens [Internet]. 2013 Mar 1 [cited 2018 Dec 7];26(3):326-33. Available from: http://www.ncbi.nlm.nih.gov/pubmed/233 82482
12. Ozaki S, Kurata M, Kumon Y, Matsumoto $\mathrm{S}$, Tagawa M, Watanabe $\mathrm{H}$, et al. Plasma thrombin-cleaved osteopontin as a potential biomarker of acute atherothrombotic ischemic stroke. Hypertens Res [Internet]. 2017 Jan 25 [cited 2018 Dec 7];40(1):61-6. Available from:

http://www.ncbi.nlm.nih.gov/pubmed/275 58929

13. Hedtjärn $M$, Mallard $C$, Hagberg $H$. Inflammatory gene profiling in the developing mouse brain after hypoxiaischemia. J Cereb Blood Flow Metab [Internet]. 2004 Dec 31 [cited 2018 Dec 7];24(12):1333-51. Available from: http://journals.sagepub.com/doi/10.1097/0 1.WCB.0000141559.17620.36

14. Carbone F, Rigamonti F, Burger F, Roth A, Bertolotto M, Spinella G, et al. Serum levels of osteopontin predict major adverse cardiovascular events in patients with severe carotid artery stenosis. Int J Cardiol [Internet]. 2018 Mar 15 [cited 2018 Dec 7];255:195-9. Available from: http://www.ncbi.nlm.nih.gov/pubmed/293 17141 